DOI:

Лариса Козіброда, кандидат наук з фізичного виховання та спорту, доичент кафедри фізичного виховання Національний університет “Львівська політехніка"

\title{
ОРГАНІЗАЦІЙНО-МЕТОДИЧНІ ЗАСАДИ ПІДГОТОВКИ ВЧИТЕЛІВ В УМОВАХ ІНКЛЮЗИВНОЇ ШКОЛИ У ФРАНЦІї
}

Стаття присвячена дослідженню організачійно-методичних основ підготовки педагогічних кадрів до роботи в умовах інклюзивного освітнього середовища у Франції. Висвітлено особливості підготовки вчителів першого і другого ступенів до впровадження інклюзивних форм навчання в освітню практику Франиії, зокрема акиентовано увагу на формуванні професійних якостей педагогів, їхніх уміннях та компетенціях, які сприяють ефективному здійсненню прочесу навчання і виховання дітей з особливими освітніми потребами. У статті наголошується, що важливим засобом забезпечення якості освітніх послуг у системі інклюзивної освіти має стати випереджальна модифікачія змісту підготовки кадрів інклюзивної освіти, що базується на безперервному навчанні та самовдосконаленні. Вона полягає в необхідності постійного вдосконалення навчальних програм, методик викладання, проведення курсів підвищення кваліфікацї та тренінгів. У франиузькій системі освіти підвищення кваліфікаиії педагогічних кадрів відбувається через лекиійні й практичні заняття, консультачії з різними фахівиями, використання спеціальних професійних он-лайн платформ.

Ключові слова: діти з особливими освітніми потребами; інклюзивна освіта; інклюзивне навчання; педагогічні кадри; франиузька система освіти; підвищення кваліфікачії.

Лim. 7.

Larysa Kozibroda, Ph.D.(Physical Education and Sports), Associate Professor of the Physical Education Department Lviv Polytechnic National University

\section{ORGANIZATIONAL-AND-METHODICAL FUNDAMENTALS OF TEACHER TRAINING IN THE CONDITIONS OF AN INCLUSIVE SCHOOL IN FRANCE}

The article is devoted to the research of organizational-and-methodological fundamentals of training the pedagogical staff to work in the conditions of inclusive educational environment in France. The peculiarities of training the first and second grade teachers for the introduction of inclusive forms of teaching in the educational practice of France have been highlighted. In particular, the emphasis has been placed on the formation of professional qualities of teachers, their skills and competences, which contribute to the effective implementation of the process of education and upbringing of children with special educational needs.

Attention has been drawn to modernization of the training of pedagogical staff providing inclusive education in France. The problems of formation of the teachers' professionalism in the field of inclusive education have been outlined. They are connected with the high level of requirements for the teachers' organizational-and-pedagogical activity, the ability to work in a team and possess the necessary legal basis. In the article it has been emphasized that an important means of providing the quality educational services in the inclusive education system should be the outstripping modification of the content of training of inclusive education staff, based on continuous learning and self-improvement. It involves the need for constant improvement of curricula, teaching methods, advanced training courses, etc. In the French education system, the advanced training of the teaching staff is provided through lectures, practical classes, consultations with various specialists, and through the use of specialized professional online platforms.

Keywords: children with special educational needs; inclusive education; pedagogical staff; French education system; advanced training.

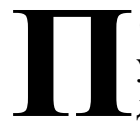

остановка проблеми. Реформа української освітньої галузі демонструє неабиякий інтерес держави до впровадження інклюзії у загальноосвітні школи 3 метою забезпечення рівного доступу до якісної освіти усім дітям, у тому числі й дітям з особливими потребами. У свою чергу, інклюзивна модель вимагає перегляду основних підходів до навчання, іншої організації розвивального середовища, а також змін у підготовці фахівців, які будуть готові до відповідних змін. Важливими елементами у підготовці вчителя до інклюзивної освіти $е$ підвищення його професійної компетентності та удосконалення умінь щодо професійної співпраці з асистентом вчителя, адміністрацією, батьками, 


\section{ОРГАНІЗАЦЙНО-МЕТОДИЧНІ ЗАСАДИ ПІДГОТОВКИ ВЧИТЕЛІВ В УМОВАХ ІНКЛЮЗИВНОЇ ШКОЛИ У ФРАНЦІЇ}

громадськими організаціями. Такі кардинальні зміни в освіті спричиняють необхідність звернення до досвіду зарубіжних країн, які розпочали впровадження інклюзивного навчання раніше і мають значну кількість напрацювань у цьому напряму.

Як демонструють сучасні дослідження українських вчених, проблеми інклюзї̈ розглядалися у кількох основних напрямах: теоретико-методологічні засади інклюзивної освіти (Т. Ілляшенко, С. Іноземцева, А. Колупаєва, В. Норченко, І. Омельченко, Л. Савчук, Т. Сак [2]), історія вивчення окресленої проблеми (Л. Донченко, А. Колупаєва, Н. Малофеєв, О. Таранченко, С. Федоренко, Т. Швець), особливості психолого-педагогічного супроводу дітей з особливими потребами (О. Андрієнко, Н. Баташева [1], В. Бондар, Н. Кулик, І. Луценко, Т. Скрипник, О. Таранченко), організація освітнього середовища для дітей з особливими потребами (Т. Бондар, І. Бочковська, С. Гайдукевич, М. Ковальова, Н. Малофеєв, І. Перерпелюк, О. Сакалюк). Окремим аспектом дослідження $\epsilon$ вивчення підготовки фахівців в Україні. Серед праць, присвячених цій проблемі виокремимо розвідки Л. Будяк, М. Васильєвої, О. Гомонюк, Л. Гречко I. Доброскок, І. Луценко, О. Мартинчук, Л. Штефан, К. Яресько та ін.

Дослідженням розвитку й організації інклюзивного навчання закордоном займалися Г. Давиденко, В. Засенко,М. Захарчук,М. Перфільєвої, А. Сбруєва [3], В. Тарасенка, С. Федоренко, Т. Фаласеніді, В. Шевцов та ін. Поміж праць, шо присвячені висвітленню історії становлення інклюзивної освіти у Франції та її окремим аспектам на сучасному етапі назвемо дослідження О. Матвієнко, Л. Перхун, Л. Пуховської, О. Сухомлинської. Незважаючи на значну кількість праць зазначеної проблематики, питання підготовки фахівців у Франції залишається малодослідженим в українській педагогічній науці.

Мета статті - вивчення досвіду Франції щодо організаційно-методичних засад підготовки педагогічних кадрів до роботи в інклюзивній школі.

Виклад основного матеріалу дослідження. Спеціальній підготовці вчителів до інклюзивного навчання у Франції передували роки теоретикометодичних та експериментальних досліджень, вивчення практичного досвіду вчителів у різних регіонах, розробка нормативно-правової бази. На сучасному етапі головним центром, що займається розробкою й впровадженням основних методичних і правових засад інклюзивної освіти у Франції є Національний інститут вищої освіти і досліджень для навчання осіб 3 особливими потребами (L'Institut national supérieur de formation et de recherche pour l'éducation des jeunes handicapés et les enseignements adaptés (INSHEA), який є інтегрованою структурою Міністерства освіти Франції. В історії становлення цієї інституції можемо виділити кілька основних етапів, які сприяли розвитку інклюзивного навчання у Франції [7]:

- 1954 рік - створення Національного центру освіти відкритого простору (Centre national d'éducation de plein air), для підготовки вчителів початкових класів до роботи $з$ дітьми-інвалідами та/або психофізичними відхиленнями;

- 1971 рік - реформування цього Центру в Національний центр досліджень й навчання для неадаптованих дітей (Centre national d'études et de formation pour l'enfance inadaptée), що розширив підготовку вчителів для спеціалізованих освітніх закладів і займався теоретичною розробкою проблем навчання і виховання дітей 3 особливими потребами;

- 2005 рік - трансформація Національного центру в Національний інститут вищої освіти і досліджень для навчання осіб з особливими потребами (INSHEA), робота якого проходить у чотирьох напрямах: дослідження щодо доступності національної системи освіти для осіб 3 особливими потребами та їх соціальнопрофесійна інтеграція у соціум; підготовка педагогічних кадрів до роботи з особами 3 особливими потребами, їх взаємодія 3 представниками сектору охорони здоров'я, соціальними структурами, громадськими організаціями, батьками; експертиза щодо впровадження і практичної реалізації інклюзивної освіти; інформування суспільства й педагогів про новітні розробки в галузі інклюзивної освіти, іiі нормативно-правове забезпечення, наукові дослідження з окресленої проблеми.

Відповідно до досліджень, проведених вченими Національного інституту вищої освіти і досліджень для навчання осіб з особливими потребами, було виокремлено чотири основні принципи, на яких повинна базуватися підготовка і подальша робота вчителів в інклюзивній школі:

1) повага до різноманітності учнів: відмінності між учнями цінуються і складають ресурс та актив для освіти;

2) супровід і підтримка всіх учнів: вчителі очікують хороших результатів від усіх без винятку учнів;

3) співробітництво з іншими вчителями та 


\section{ОРГАНІЗАЦІЙНО-МЕТОДИЧНІ ЗАСАДИ ПІДГОТОВКИ ВЧИТЕЛІВ В УМОВАХ ІНКЛЮЗИВНОЇ ШКОЛИ У ФРАНЦЇ̈}

працівниками, що забезпечують супровід дітей 3 особливими потребами: командна робота важливий елемент для всіх учасників педагогічного процесу, що сприяє створенню ефективного освітнього середовища для кожної дитини;

4) постійний особистісний професійний розвиток: навчання - це діяльність, яка спрямована на постійне удосконалення своїх професійних якостей, і вчителі повинні взяти на себе відповідальність за власне навчання упродовж усього життя.

Важливо зазначити, що при підготовці вчителів до роботи в інклюзивній школі у Франції передбачено два напрями: перший - підвищення кваліфікації вже працюючих вчителів через їх неперервне навчання та другий - підготовка майбутніх вчителів з урахуванням нових вимог інклюзивної освіти. Пріоритетну роль у підготовці фахівців інклюзивної школи відграє тісна співпраця між закладами вищої освіти, що надають освітні послуги майбутнім учителям та школами різного типу з метою набуття практичного досвіду. Така командна робота сприяє формуванню необхідних професійних компетентностей, умінь співпрацювати з різними структурами з одного боку, а з іншого пропагувати ідеї інклюзії серед шкільної громади, батьків, місцевої спільноти [5, 179].

Слід також зауважити, що навчання впродовж життя $є$ ключовим елементом професійного зростання вчителів. У французькій системі освіти підвищення кваліфікації педагогічних кадрів відбувається постійно через лекційні й практичні заняття, консультації з різними фахівцями, 3 використанням спеціальних он-лайн платформ, якто "CAP école inclusive" [4], що сприяє навчанню учнів з особливими потребами або обмеженими можливостями, надаючи освітні ресурси для методичної підтримки та консультації вчителів початкових та середніх шкіл, а також майбутніх фахівців.

Поміж аспектів, що пропонуються на цій платформі назвемо такі:

- фільми, що спряють сенсибілізації дітей та підлітків до людей з інвалідністю. Наголосимо що метою таких фільмів $є$ краще розуміння щоденних труднощів, з якими стикаються молоді люди 3 обмеженими можливостями, показ їхній психологічних проблем, прищеплення поваги до різності людей у певній соціальній групі;

- подкасти для розуміння різних розладів як 3 наукової, так і з навчальної точки зору (наприклад про вплив порушень на навчання);

- вкладки "педагогічна адаптація" - аркуші, які класифіковані за видами адаптації і які можна використовувати безпосередньо у навчальному процесі;

- можливість контактувати з експертомвикладачем 3 навчання осіб $з$ особливими освітніми потребами.

3 метою покращення врахування спеціальних освітніх потреб учнів, Міністерством освіти Франції учителям та майбутнім педагогам запропоновано пройти низку тренінгів та курсів, що складаються з модулів і розраховані на кілька років задля забезпечення якості підготовки та урахування нагальних потреб інклюзивної школи.

Відповідно до Наказу від 5 червня 2019 року [6] тренінги організовані у трьох напрямах, що розділені на тригодинні модулі:

1) інституційні системи (3 модулі);

2) потреби студентів з обмеженими можливостями (7 модулів);

3) компетенції, пов'язані із покладеними завданнями (10 модулів).

Варто наголосити, що наскрізною ідеєю у підготовці та у процесі підвищення кваліфікації педагогічних кадрів $€$ їх тісна взаємодія з різними відомчими службами, 3 іншими учителями, керівним і допоміжним персоналом задля узгодження навчальних дій та забезпечення ефективного здійснення інклюзивних навчальновиховних заходів у школі. Коли йдеться про тісну співпрацю між учителями, то передусім наголошено не тільки на спільному проведенні уроків, але й спільному плануванні та оцінюванні досягнень учнів між педагогами. Такий підхід є ефективним з огляду на задоволення потреб усіх учасників навчального процесу, правильний розподіл часу кожного вчителя та/або асистента вчителя.

Висновки. Отже у системі інклюзивної освіти Франції важлива роль відводиться підготовці педагогічних кадрів, які б були експертами у питаннях не тільки організації навчального процесу, але й володіли нормативно-правовою базою 3 зазначеної проблеми, уміли взаємодіяти із різними інституційними, суспільними й громадськими ланками локальної громади задля ефективного забезпечення потреб осіб з особливими освітніми потребами. Головними навичками, якими повинен володіти вчитель інклюзивної школи Франції визначаються такі: цінності, ставлення, кваліфікація, знання та розуміння потреб кожної дитини. Вчитель повинен бути озброєним теоретико-методичними знаннями, уміти їх використовувати у практичній діяльності, знати способи оцінювання досягнень учнів i, безперечно володіти сучасними підходами, методами й технологіями щодо навчання дітей з особливими освітніми потребами. 
Водночас, як зазначається в офіційних документах, педагоги, які навчені ефективно працювати з учнями із різноманітними потребами, служать мультиплікаторами для інклюзивної освіти, адже будь-яка дія, яка сприяє інклюзивній освіті $\epsilon$ важливою для поширення ідей інклюзивного навчання, що має довгострокову перспективу.

\section{ЛIТЕРАТУРА}

1. Баташева Н. Особливості перцептивного та когнітивного компонентів емоційної сфери дошкільників із затримкою психічного розвитку. Особлива дитина: навчання і виховання. 2017. № 2. С. $48-55$.

2. Сак Т. Індивідуалізація навчання учнів 3 особливими освітніми потребами в інклюзивному класі. Особлива дитина: навчання $і$ виховання. 2014. № 4. C. 18-23.

3. Сбруєва А. А. Тенденції реформування середньої освіти розвинених країн в контексті глобалізації (90-і рр. XX - XXI ст.) : монографія. Суми : Сумська обласна друкарня; вид-во "Козацький вал”, 2004. 500 с.

4. Cap école inclusive. La plateforme dédiée à l'école inclusive URL: https://primabord.eduscol.education.fr/ cap-ecole-inclusive (дата звернення: 30.11.2019)

5. Ciambrone R. Des classes différenciées aux besoins éducatifs spéciaux. L'évolution du modèle inclusif en Italie. La nouvelle revue Éducation et société inclusives. 2018. № 82. P. 171-183.

6. Circulaire de rentrée 2019. École inclusive URL: https://handicap.gouv.fr/IMG/pdf/2019 dp_ecole_inclusive.pdf (дата звернення: $01 . \overline{12} .2019 \overline{)}$

7. INSHEA. URL: http://www.inshea.fr/fr/ content/notre-histoire (дата звернення: 30.11.2019)

\section{REFERENCES}

1. Batasheva, N. (2017). Osoblyvosti pertseptyvnoho ta kohnityvnoho komponentiv emotsiinoi sfery doshkilnykiv iz zatrymkoiu psykhichnoho rozvytku [The features of perceptual and cognitive components of the emotional sphere of preschool children with mental retardation]. Special child: education and upbringing. No. 2. pp. 48-55. [in Ukrainian].

2. Sak, T. (2014). Indyvidualizatsiia navchannia uchniv z osoblyvymy osvitnimy potrebamy $\mathrm{v}$ inkliuzyvnomu klasi [Individualization of learning for students with special educational needs in an inclusive classroom]. Special child: education and upbringing. No. 4. pp. 18-23. [in Ukrainian].

3. Sbruieva, A. A. (2004). Tendentsii reformuvannia serednoi osvity rozvynenykh krain $\mathrm{v}$ konteksti hlobalizatsii (90-i rr. XX - XXI st.) : monohrafiia [Trends in the reformation of secondary education in developed countries in the context of globalization (90s of XX - XXI centuries): monograph]. Sumy, 500 p. [in Ukrainian].

4. Cap école inclusive. La plateforme dédiée à l'école inclusive [Inclusive school course. The platform dedicated to inclusive school]. Available at: https://primabord.eduscol.education.fr/capecole-inclusive (accessed 30 Nov. 2019). [in French].

5.Ciambrone, R. (2018). Des classes différenciées aux besoins éducatifs spéciaux. L'évolution du modèle inclusif en Italie. La nouvelle revue Éducation et société inclusives [Differentiated classes with special educational needs. The evolution of the inclusive model in Italy]. No. 82. pp. 171-183. [in French].

6. Circulaire de rentrée 2019. École inclusive [Inclusive School]. Available at: https:// h a n d i c a p.g o u v. fr/I M G/p d f/ 2019_dp_ecole_inclusive.pdf (accessed 01 Dec.2019). [in French].

7. INSHEA. URL: http://www.inshea.fr/fr/ content/notre-histoire (accessed 30 Nov.2019) [in French].

Стаття надійшла до редакції 23.12.2019

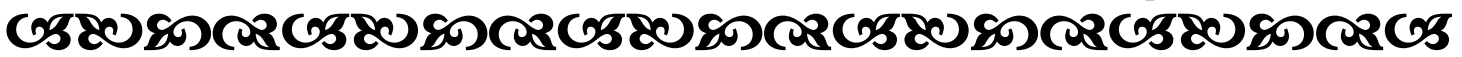

“...Один із сеқретів педагогічної творчості в тому, щоб пробудити у викладача інтерес до пошуку, до аналізу власної роботи”.

\section{Василь Сухомлинський \\ украӥнський педагог}

“Вихователь має вести себе так щоб кожен його рухвиховував, ізавжди має знати, чого він хоче саме зараз, $і$ чого не хоче. Якщо вихователь не знає иього, кого він може виховати?" 